\title{
Artur Zaborski*
}

\section{THE PRESENTATION OF CHANGES IN PREFERENCES BY DYNAMIC SCALING}

\begin{abstract}
Dynamic scaling is a set of methods in which the geometrical representation of the similarity data for $T$ different time periods is made. This article presents the use of two-dynamic scaling methods for studying changes in the preferences. In the first method the location of points on the perceptual map is made on the basis of the super-dissimilarity matrix. In the second method multidimensional scaling for the respective periods is carried out and the obtained configurations are matched by transformations preserving the proportions of distances between points. The presentation of the methods is illustrated by an empirical example in which calculations were performed with use of SPSS and New MDSX packages.
\end{abstract}

Keywords: preference analysis, similarity matrix, dynamic scaling, Procrustes analysis.

JEL: C38, C63, M31

\section{INTRODUCTION}

The analysis of changes in consumer preferences by using the multidimensional scalingmethods is often performed based on preferences matrices for different periods. These matrices do not always meet the symmetry condition (see e.g.: Holyoak, Gordon 1983; Tversky, Gati 1982; Harshman et al. 1982; Chino 1978). The elements $p_{i j}(i, j=1,2, \ldots, n, n$ - number of objects) of those matrices may show the number of people declaring that the object $j$ is theirtop priority, even though in the earlier period it was the object $i$, the likelihood that the consumer is purchasing brand $j$ on condition that on the previous purchases it was brand $i$, and the like.

Several algorithms and models of multidimensional scaling for asymmetric data have been introduced in the last three decades. Some of them deal with twomode three-way proximities (see e.g.: Zielman, Heiser 1993, DeSarbo et al. 1992, Okada, Imaizumi 1997), and some deal with one-mode two-way proximities (see e.g.: Borg, Groenen 2005: 495-516, Okada, Imaizumi 2007).

\footnotetext{
* Ph.D., Department of Econometrics and Computer Science, Wrocław Univeristy of Economics.
} 
Because each asymmetric proximity square matrix $\mathbf{P}$ can be decomposed by presentation as the sum of the symmetric matrix $\mathbf{A}$ and the skew-symmetric matrix $\mathbf{B}$, where:

$$
\sum_{i, j} p_{i j}^{2}=\sum_{i, j} a_{i j}^{2}+\sum_{i, j} b_{i j}^{2}
$$

the analysis of the data contained in the asymmetric proximity matrix may consist of two parts: the analysis of the symmetrical components and the analysis of the skew-symmetric components. Hence, the division of multidimensional scaling methods for asymmetric data into three groups:

- methods based on the analysis of matrix $\mathbf{P}$ (e.g. unfolding, slide vector model, hill-climbing model, dominance point model),

- methods based on the analysis of matrix $\mathbf{B}$, or on the matrices $\mathbf{A}$ and $\mathbf{B}$ (e.g. signed-distance model, radius-distance model, drift vectors model),

- methods based on the analysis of matrix A (dynamic scaling).

A method belonging to the third group (dynamic scaling) is the method of analysing similarity data for a set of objects obtained at the analysis of similarities between objects for $T$ successive time periods. The aim of the procedure is to present on the perceptual map a configuration of $n T$ points, where each of $n$ points representing the objects is shown $T$ times, once for each of the time periods. Plotting the path over time of $T$ points for each object insight into the changes in preferences with respect to time.

The article presents two methods of dynamic scaling: the method which used in its construction the Procrustes analysis and dynamic scaling based on a super-similarity matrix.

\section{DYNAMIC SCALING WITH THE USE OF PROCRUSTES ANALYSIS}

Carrying out multidimensional scaling for similarities data obtained for different periods, and then showing them on one perceptual map is not appropriate because the differences in the points' configurations on the maps do not always arise from the differences in the perception of objects by respondents. The method that allows to lead the comparability of the perceptual maps obtained for different time periods is the Procrustes analysis, which is usually used in individual differences models. In the Procrustes analysis one configuration matches another in such a way that the proportions of distances between corresponding points are maintained. 
For two results of multidimensional scaling $\mathbf{X}=\left[\mathbf{x}_{1}, \mathbf{x}_{2}, \ldots, \mathbf{x}_{n}\right]^{T}$ and $\mathbf{Y}=\left[\mathbf{y}_{1}, \mathbf{y}_{2}, \ldots, \mathbf{y}_{n}\right]^{T}$ (points $\mathbf{X}$ and $\mathbf{Y}$ represent the same objects obtained at different time periods) the matching configuration is the best if the sum of squares of the distances between the corresponding points $\mathbf{X}$ and $\mathbf{Y}$ is the smallest. In order to match the configuration $\mathbf{X}$ to the $\mathbf{Y}$ points $\mathbf{X}$ are put to transformations, which are translation, rotation and dilation. Adjusting the configuration by the Procrustes analysis runs through the following steps (Borg,Groenen2005: 434-436, Cox, Cox 2001: 124-128, Zaborski 2007):

- translate configurations $\mathbf{X}$ and $\mathbf{Y}$ so that they both have their centroids at the origin,

- rotate the $\mathbf{X}$ configuration to $\mathbf{X E}$, where $\mathbf{E}=\frac{\left(\mathbf{X}^{T} \mathbf{Y} \mathbf{Y}^{T} \mathbf{X}\right)^{1 / 2}}{\left(\mathbf{X}^{T} \mathbf{X}\right)}$,

- scale the $\mathbf{X}$ configuration by multiplying each coordinate by $\hat{\varphi}=\frac{\operatorname{tr}\left(\mathbf{X}^{T} \mathbf{Y} \mathbf{Y}^{T} \mathbf{X}\right)^{1 / 2}}{\operatorname{tr}\left(\mathbf{X}^{T} \mathbf{X}\right)}$,

- calculate a Procrustes statistic: $R^{2}=1-\frac{\left\{\operatorname{tr}\left(\mathbf{X}^{T} \mathbf{Y} \mathbf{Y}^{T} \mathbf{X}\right)^{1 / 2}\right\}^{2}}{\operatorname{tr}\left(\mathbf{X}^{T} \mathbf{X}\right) \operatorname{tr}\left(\mathbf{Y}^{T} \mathbf{Y}\right)}$.

The dynamic scaling method which uses the Procrustes analysis is taken by simply carrying out the multidimensional scaling analysis for each time period separately, and then matching the obtained configurations to the first period configuration. Alternatively, the second configuration could have been matched to the first one, the third to the second one and so on.

\section{EMPIRICAL EXAMPLE}

The objective of the study was to analyse changes in the preferences' similarities of the University of the Third Age members in Boleslawiec (Lower Silesia Province). Table 1 shows changes which occurred in the choices made by the University members in the activities in each year from 2009 to 2013. The study involved 109 people who regularly participated in activities within a definite period of time. Elements of the $i$-throw and the $j$-th column show the number of members who at the beginning of the period chose the $i$-th class, and the $j$-th class at the end of the period. The presented matrix should be considered as a similarity matrix because the high value of an element means that students willingly switch activities, and in accordance with their preference, they treat them as similar. 
Table 1. Switching data among classes in subsequent years

\begin{tabular}{|c|c|c|c|c|c|c|c|c|c|c|}
\hline \multicolumn{2}{|r|}{ Classes } & Engl. & Germ. & $\begin{array}{c}\text { Com } \\
\text { pp. }\end{array}$ & Gym. & Yoga & Swim. & Weight & Nord. & Paint. \\
\hline & English & 22 & 0 & 1 & 1 & 3 & 0 & 0 & 0 & 0 \\
\hline & German & 1 & 15 & 2 & 2 & 4 & 1 & 1 & 1 & 0 \\
\hline & Computer skills & 2 & 0 & 5 & 4 & 5 & 4 & 4 & 0 & 1 \\
\hline ㄱ. & Gymnastics & 0 & 0 & 0 & 50 & 4 & 2 & 2 & 1 & 1 \\
\hline î & Yoga & 0 & 0 & 0 & 0 & 9 & 3 & 1 & 0 & 1 \\
\hline ¿্ণ & Swimming & 0 & 0 & 0 & 2 & 0 & 22 & 2 & 2 & 0 \\
\hline & Weight training & 0 & 0 & 0 & 0 & 0 & 0 & 5 & 0 & 0 \\
\hline & Nordic walking & 0 & 0 & 0 & 0 & 0 & 0 & 0 & 8 & 0 \\
\hline & Painting and handicraft & 0 & 0 & 2 & 0 & 0 & 0 & 0 & 1 & 7 \\
\hline \multirow{9}{*}{$\begin{array}{l}\bar{\Xi} \\
0 \\
0 \\
0 \\
\text { ㅇ. }\end{array}$} & English & 14 & 0 & 0 & 3 & 0 & 2 & 1 & 0 & 0 \\
\hline & German & 0 & 9 & 1 & 1 & 2 & 4 & 0 & 1 & 1 \\
\hline & Computer skills & 0 & 0 & 11 & 1 & 0 & 2 & 1 & 1 & 0 \\
\hline & Gymnastics & 0 & 0 & 0 & 56 & 2 & 2 & 0 & 1 & 0 \\
\hline & Yoga & 0 & 0 & 0 & 1 & 18 & 4 & 0 & 2 & 0 \\
\hline & Swimming & 1 & 0 & 0 & 1 & 2 & 25 & 1 & 2 & 0 \\
\hline & Weight training & 0 & 0 & 0 & 0 & 1 & 1 & 8 & 0 & 0 \\
\hline & Nordic walking & 0 & 0 & 0 & 0 & 0 & 0 & 0 & 7 & 0 \\
\hline & Painting and handicraft & 0 & 0 & 0 & 0 & 0 & 0 & 0 & 0 & 8 \\
\hline \multirow{9}{*}{ 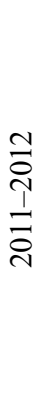 } & English & 19 & 1 & 0 & 0 & 1 & 0 & 0 & 0 & 0 \\
\hline & German & 0 & 8 & 0 & 1 & 1 & 0 & 0 & 0 & 0 \\
\hline & Computer skills & 0 & 0 & 7 & 2 & 2 & 2 & 0 & 0 & 0 \\
\hline & Gymnastics & 0 & 0 & 1 & 55 & 4 & 5 & 3 & 0 & 0 \\
\hline & Yoga & 1 & 0 & 0 & 1 & 17 & 1 & 0 & 2 & 0 \\
\hline & Swimming & 0 & 0 & 0 & 0 & 0 & 41 & 1 & 0 & 0 \\
\hline & Weight training & 0 & 0 & 0 & 1 & 0 & 0 & 9 & 0 & 0 \\
\hline & Nordic walking & 0 & 0 & 0 & 0 & 1 & 1 & 0 & 12 & 0 \\
\hline & Painting and handicraft & 0 & 0 & 0 & 0 & 0 & 0 & 0 & 0 & 12 \\
\hline \multirow{9}{*}{ 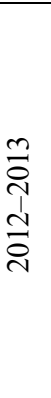 } & English & 20 & 0 & 0 & 1 & 0 & 1 & 0 & 1 & 0 \\
\hline & German & 0 & 8 & 0 & 0 & 0 & 1 & 0 & 0 & 0 \\
\hline & Computer skills & 0 & 0 & 10 & 1 & 0 & 0 & 2 & 0 & 0 \\
\hline & Gymnastics & 0 & 0 & 1 & 48 & 3 & 2 & 3 & 2 & 0 \\
\hline & Yoga & 0 & 0 & 0 & 0 & 15 & 1 & 0 & 2 & 0 \\
\hline & Swimming & 0 & 0 & 0 & 3 & 1 & 47 & 2 & 1 & 0 \\
\hline & Weight training & 0 & 0 & 0 & 0 & 0 & 3 & 11 & 0 & 0 \\
\hline & Nordic walking & 0 & 0 & 0 & 1 & 0 & 0 & 0 & 11 & 0 \\
\hline & Painting and handicraft & 0 & 0 & 0 & 0 & 0 & 0 & 0 & 0 & 9 \\
\hline
\end{tabular}

Source: own elaboration. 
Based on the similarity matrices contained in Table 1 the dynamic scaling was performed, where all configurations were fitted by the Procrustes analysis to the configuration of the first analyzed period. The dynamic map showing the trajectory of perceptual changes in the preference similarities is presented in Figure 1.

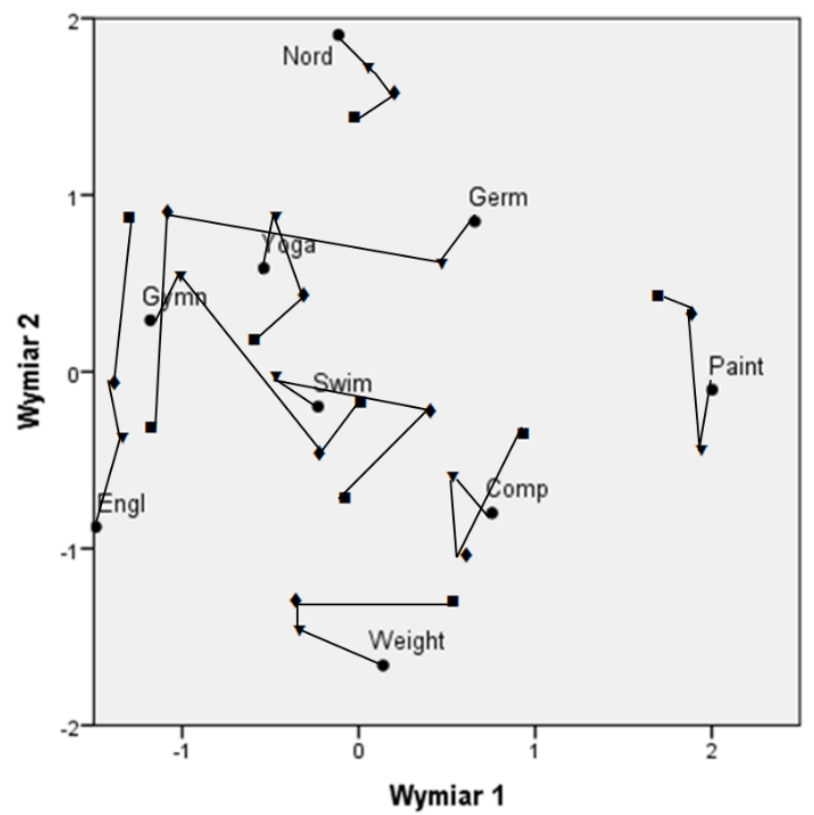

Figure 1. Dynamic perceptual map using Procrustes analysis

Source: own elaboration.

The layout of points in Figure1 indicates that in the analyzed period, the biggest changes in position on the map of preference similarities occurred for foreign languages, especially for German. In the first analyzed period it is difficult to observe activities that the students of the University treated as similar in terms of preferences. In the period 2011-2013 a group of classes that are similar in preference are gymnastics, swimming and yoga.

\section{DYNAMIC SCALING BASED ON SUPER-SIMILARITY MATRIX}

Another possibility of geometrical representation of $T$ sets of objects on one perceptual map is a multidimensional scaling based on a super-similarity matrix $\mathbf{P}$ : 


$$
\mathbf{P}=\left[\begin{array}{cccc}
\mathbf{P}_{11} & \mathbf{P}_{12} & \cdots & \mathbf{P}_{1 T} \\
\mathbf{P}_{21} & \mathbf{P}_{22} & \cdots & \mathbf{P}_{2 T} \\
\vdots & \vdots & \ddots & \vdots \\
\mathbf{P}_{T 1} & \mathbf{P}_{T 2} & \cdots & \mathbf{P}_{T T}
\end{array}\right],
$$

where:

$\mathbf{P}_{t t}-$ the similarity matrix formed from similarities $p_{i j}^{t}$ collected in the $t$-th time period,

$\mathbf{P}_{t s}=\left[p_{i j}^{t s}\right]-$ the similarity matrix, where $p_{i j}^{t s}$ is the similarity of object $i$ in the $t$-th time period with object $j$ in the $s$-th time period $(t \neq s)$,

$t, s=1,2, \ldots, T ; i, j=1,2, \ldots, n$.

If the similarities $p_{i j}^{t s}$ cannot be found they can be constructed as:

$$
p_{i j}^{t s}=\frac{1}{2}\left(p_{i j}^{t}+p_{i j}^{s}\right)
$$

The next possibility is to assume that all $p_{i j}^{t s}$ are missing, or to define $p_{i j}^{t s}=0$ (see: Cox, Cox 2001: 100).

The same data which was presented in section 3 has been used to perform the dynamic scaling based on the super-similarity matrix. The result of the analysis is presented in Figure 2.

The points distribution in Figure 2 leads to similar conclusions as those which were obtained from the dynamic scaling with the use of the Procrustes analysis. In the first time period (see points with the name of classes) it is difficult to notice the similarity in preferences with respect to the activities - the exceptions are swimming and yoga. Because it was the beginning of the functioning of the University, students probably were not fully aware of their expectations and the choices were random. Points representing gymnastics, swimming, yoga and Nordic walking in 2013 are close to the center of the perceptual map, what allows to treat them as similar. Points representing the remaining classes are located on the outskirts of the ma pp.

For such performed multidimensional scaling the stress is 0.1008 and the Tucker congruence factor is 0.9483 , what indicates a good fit to the input data. 


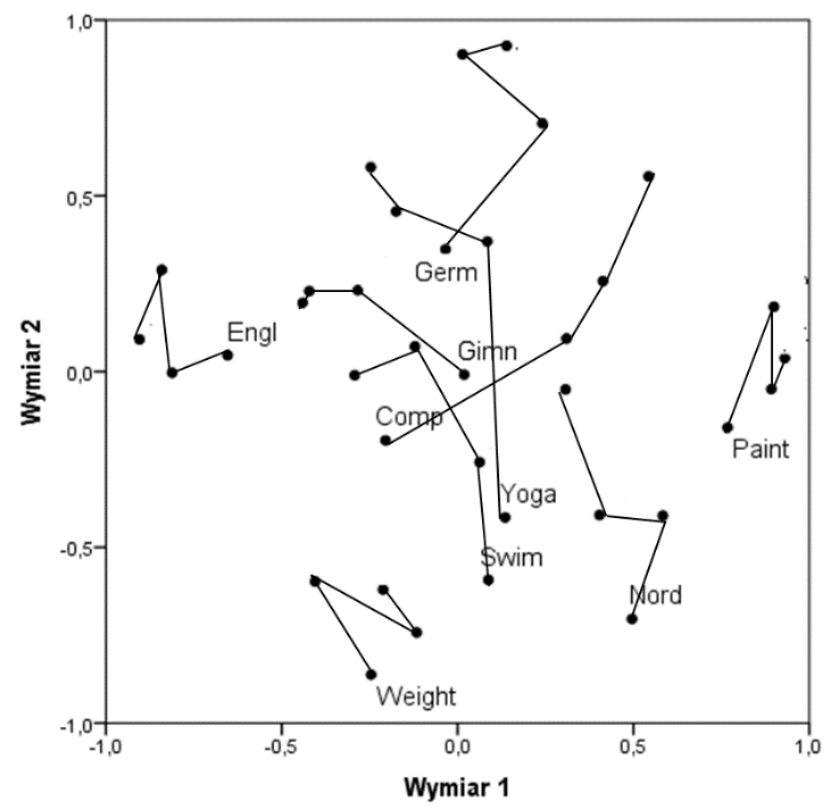

Figure 2. Dynamic perceptual map for MDS based on super-similarity matrix

Source: own elaboration.

\section{CONCLUSIONS}

The article presents two methods of dynamic scaling which were used to show the trajectory of changes in preferences. The first method is taken by simply carrying out the multidimensional scaling for each time period separately, and then matching the obtained configurations by the Procrustes analysis to the first period configuration. In the second method the geometrical representation of $T$ sets of $n$ objects on the one perceptual map is made by the multidimensional scaling based on the super-similarity matrix.

The use of both methods confirmed that at the beginning of the analyzed period it was difficult to notice similarities in the preferences of members of the University of the Third Age with respect to forms of classes, but as time went by preferences were clearly moving towards activities that improve mobility.

\section{REFERENCES}

Borg I., Groenen P. (2005), Modern multidimensional scaling. Theory and applications. Second Edition, Springer-Verlag, New York.

Chino N. (1978), A graphical technique for representing the asymmetric relationship between Nobjects, "Behaviometrika", no. 5, pp. 23-40. 
Cox T.F., Cox M.A.A. (2001), Multidimensional Scaling. Second Edition, Chapman and Hall, London.

DeSarbo W. S., Johnson M.D., Manrai A.K., Manrai L.A., Edward E.A. (1992), TSCALE: A New Multidimensional Scaling Procedure Based on Tversky's Contrast Model, "Psychometrika", 57, pp. 43-69.

Harshman R.A., Green PP.E., Wind Y., Lundy M.E. (1982), A model for the analysis of asymmetric data in marketing research, "Marketing Science", vol. I, no. 2, pp. 205-242.

Holyoak K.J., Gordon PP.C. (1983), Social reference points, "Journal of Personality and Social Psychology", no 44, pp. 881-887.

Okada A., Imaizumi T. (1997), Asymmetric multidimensional scaling of two-mode three-way proximities, "Journal of Classification,", no. 14, pp. 195-224.

Okada A., Imaizumi T. (2007), Multidimensional scaling of asymmetric proximities with a dominance point, "Advances in Data Analysis Studies in Classification, Data Analysis, and Knowledge Organization”, (red.) R. Decker, H.J. Lenz, Springer-Verlag, Berlin, Heidelberg, pp. 307-318.

Tversky A., Gati I. (1982), Features of similarity, "Psychological Review”, no. 89, pp. 123-154.

Zaborski A., (2007), Przegląd wybranych modeli różnic indywidualnych $w$ skalowaniu wielowymiarowym, Prace Naukowe Akademii Ekonomicznej we Wrocławiu, nr 1151, s. $9-18$.

Zielman B., Heiser W.J. (1996), Analysis of Asymmetry by a Slide-Vector, "Psychometrika", 58, pp. 101-114.

\section{Artur Zaborski}

\section{PREZENTACJA ZMIAN ZACHODZACYCH W PREFERENCJACH Z WYKORZYSTANIEM SKALOWANIA DYNAMICZNEGO}

Streszczenie: Skalowanie dynamiczne jest zbiorem metod, w których dokonuje się geometrycznej prezentacji danych podobieństw uzyskanych dla $T$ różnych okresów. Celem artykułu jest przedstawienie zastosowania dwóch metod skalowania dynamicznego do badania zmian zachodzących $w$ preferencjach. W pierwszej, rozmieszczenia punktów na mapie percepcyjnej dokonuje się $\mathrm{w}$ na podstawie rozbudowanej macierzy podobieństw. W drugiej metodzie przeprowadza się skalowanie wielowymiarowe dla poszczególnych okresów, a następnie dopasowuje otrzymane konfiguracje punktów za pomocą przekształceń zachowujących proporcje odległości między punktami. Prezentacja metod zostanie zilustrowana przykładem empirycznym, w którym obliczenia przeprowadzono z wykorzystaniem pakietów SPSS i New MDSX.

Słowa kluczowe: badanie preferencji, macierz podobieństw, skalowanie dynamiczne, analiza Procrustesa. 